\title{
Value of Individual and Bulk Milk Serology for Surveillance and Evaluation of Vaccination Programs Used in Dairy Farms in Egypt to Control FMD Virus Infection
}

\author{
Adel Abdel-Azeem Fayed ${ }^{1}$, Mounir Mohamed Abdel-Halim ${ }^{1}$, Nabila Shaker \\ Degheidy ${ }^{2}$, Mohamed Karam EL-Bayoumy ${ }^{3}$ and Hiam Mohamed Fakry ${ }^{4}$ \\ ${ }^{1}$ Department of Infectious Diseases, Faculty of Veterinary Medicine, Cairo University, Egypt \\ ${ }^{2}$ College of Sciences, Taif University, Saudi Arabia \\ ${ }^{3}$ Department of Parasitology and Animal Diseases, National Research Center, Egypt \\ ${ }^{4}$ Department of Foot and Mouth disease virus, Veterinary Vaccine and Serum Research institute, \\ Egypt
}

Correspondence should be addressed to: Mohamed Karam EL-Bayoumy; mhdkaram@hotmail.com

Received 17 May 2013; Accepted 23 June 2013; Published 29 October 2013

Academic Editor: Frank Norbert Mwiine

Copyright (C) 2013 Adel Abdel-Azeem Fayed, Mounir Mohamed Abdel-Halim, Nabila Shaker Degheidy, Mohamed Karam EL-Bayoumy and Hiam Mohamed Fakry. Distributed under Creative Commons CC-BY 3.0

\begin{abstract}
From three commercial Friesian-Holstein dairy herds located in three different provinces of Egypt at El-Fayoum, EL-Ismailia, and EL-Beheira; a total of 183 paired serum and milk samples were collected on the same occasion and 23 Bulk Tank Milk (BTM) samples were collected for about a year. Samples were tested and evaluated to monitor the immune status of vaccinated cattle against Foot and Mouth Disease (FMD) virus (strain 01/93/ Aga / Egypt). All samples were subjected to Indirect Enzyme-linked immunosorbent assay (ELISA) test and Serum neutralization test (SNT) for the detection of specific antibodies. Although Milk is easier and more acceptable than blood sampling for surveys in many situations, results have revealed a significant correlation $(r>6, \mathrm{P}<0.01)$ between individual serum and milk titers. BTM permit an adequate determination of immune status representing individual milk samples in dairy herds, it permits an adequate determination of Herd Protection level (HPL) but with different cut-off values according to different conditions of management. In addition, the number of vaccination was adopted in each herd; vaccination of dairy herds for three times annually is the number of choice for sufficient economic protective antibody titer all round the year.
\end{abstract}

Keywords: Bulk Tank Milk, ELISA, FMD, Milk, SNT, Vaccine.

Cite this Article as: Adel Abdel-Azeem Fayed, Mounir Mohamed Abdel-Halim, Nabila Shaker Degheidy, Mohamed Karam EL-Bayoumy and Hiam Mohamed Fakry (2013), "Value of Individual and Bulk Milk Serology for Surveillance and Evaluation of Vaccination Programs Used in Dairy Farms in Egypt to Control FMD Virus Infection," International Journal of Veterinary Medicine: Research \& Reports, Vol. 2013 (2013), Article ID 730973, DOI: 10.5171/2013.730973 


\section{Introduction}

Although clinical Foot-and-Mouth disease (FMD) is confirmed by virus isolation and typing, serological surveillance has also been widely used to confirm absence of infection. While blood samples are usually obtained for FMD virus antibody detection, milk could be a useful alternative. Collection of milk is non invasive and its testing would thus be an easier and more acceptable means than blood sampling for surveys in many situations Armstrong (1997). Therefore, serological evaluation of milk against different infectious diseases provides farmers and veterinarians with a potentially very useful and inexpensive method of initiating disease investigations and monitoring the presence of common endemic infections in the herd. The noninvasive method of sampling also readily lends itself to use in research studies and epidemiological surveys, Pritchard et al., (2002).

Foot-and-mouth disease (FMD) virus is the etiologic agent of the disease that can affect cloven-hoofed livestock; it causes an acute disease characterized by fever, lameness and vesicular lesions on the feet, tongue and teats, with high morbidity and low mortality Depa et al., (2012). FMD is enzootic in many developing regions of Asia, Africa and South America that lack adequate veterinary services and resources necessary to undertake control and eradication efforts. Rodriguez and Grubman (2009) and Sumption et al., (2008), countries from which the disease is absent maintain their FMD-free status using strict import controls, in endemic regions; vaccination is the major means of FMD control Armstrong (2000).

Serological surveillance for FMD has been performed conventionally by using virus neutralization test (VNT) Golding et al., (1976), the enzyme linked immunosorbent assay (ELISA) for antibody detection which is a fast inexpensive and simple method for screening large number of test samples; using this technique on pooled samples (e.g. bulk tank milk samples), the conditions for a low-cost monitoring program are satisfied Nylin et al., (2000). Serological testing of FMD is useful in determining the potency of vaccines, epidemiological studies and evaluation of animals to ensure whether they have been recently infected and or vaccinated VanMaanen (1990). In addition to Bulk milk tests value for serological monitoring, it is envisaged that veterinary practices could record the information from bulk milk tests and incorporate it into preventive medicine programs, particularly in relation to purchased animals. Regular testing of bulk milk samples every few months provides a simple low cost method of confirming continuing freedom from infection in known disease-free herds; including those at potential risk of introducing new infection Zadnik et al., (2001), therefore, the present article was carried out to:-

1- Investigate and evaluate the vaccination program in some dairy herds by identifying antibody responses against FMD virus in individual milk and serum to monitor the immune status of vaccinated cattle.

2- Study the significance and correlation between serum and milk samples for evaluation of vaccination program in different herds, and the ability of using bulk tank milk to represent individual milk samples.

\section{Materials and Methods}

\section{Vaccinated Animals and Samples:}

Three commercial "Friesian-Holstein" dairy herds coded "A","B" and "C" located in ElFayoum, EL-Ismailia and EL-Beheira provinces respectively were investigated. One thousand and five hundred, 600 and 600 dairy cattle were presented in "A","B" and " $\mathrm{C}$ " herds respectively. Fifty five, 66 and 62 paired serum and milk samples were collected on the same occasion from 30 animals (10 animals representing each herd) through 51, 41 and 54 weeks from herds A, B and C respectively. Eight, 7 and 8 BTM samples representing all dairy animals in the farm were collected from herds $\mathrm{A}, \mathrm{B}$ and $\mathrm{C}$ respectively. 
Paired Blood $(10 \mathrm{ml})$ and milk samples $(25 \mathrm{ml})$ were collected all over the year from the three dairy herds Within 24 hours; serum was harvested and stored at $80^{\circ} \mathrm{C}$. Sera used in SNT were inactivated for 30 minutes in a water bath at $56^{\circ} \mathrm{C}$ Edwards et al., (1986). According to Niskanen et al., (1991) skim milk (from underneath the fat layer) was collected after centrifugation for 10 minutes $3000 \mathrm{xg}$ at $4^{\circ} \mathrm{C}$ in cooling centrifuge.

\section{Vaccination Program:}

All animals in the three herds were vaccinated with binary ethylenimine (BEI) inactivated aluminum hydroxide adjuvant, FMD Virus type $0_{1} / 93 /$ Aga vaccine, (Veterinary Serum and Vaccine ResearchCairo-Egypt). They were vaccinated four, three times and twice annually in herds A, $\mathrm{B}$ and $\mathrm{C}$ respectively.

\section{Reference Control Sera:}

-Reference hyperimmune sera against FMD Virus type "O" "FMD department, Veterinary Serum and Vaccine Research Institute, Cairo, Egypt".

-Newborn calf serum "Selborn Biological services, Tasmania, Australia"

\section{Assay Procedure:}

\section{FMD Indirect ELISA:}

\section{Preparation of FMD Antigen:}

FMD virus (strain $0_{1} / 93$ / Aga / Egypt) propagated in BHK-21 cell culture was prepared according to (Wagner et al., 1969). Measurement of protein concentration was applied according to (Bradford, 1976).

Checkerboard titrations of milk samples were carried out by the method described by Armstrong II (1997).

\section{FMD ELISA Procedure:}

The indirect ELISA was carried out by the method described by (Voller et al., 1976). Checkerboard titration was performed with $100 \mu$ volumes of antigen, serum and conjugate to determine optimal dilutions. PBS containing $0.05 \%$ Tween 20 was used for washing and dilutions. Flat bottomed ELISA plates "greiner bio-one" (96 wells) were coated with FMD antigen by adding $100 \mu \mathrm{l}$ of antigen diluted in carbonate bicarbonate buffer $1 / 140$ as determined by Checkerboard titration, Checkerboard titrations of milk samples were carried out by the method described by Armstrong II (1997). Plates were then incubated at $4^{\circ} \mathrm{C}$ overnight, and then the plate contents were decanted and washed three times with washing buffer, and dried. The coated plate was blocked by adding $100 \mu$ l of blocking buffer (PBS buffer with 3\% serum bovine albumin) per well and incubated over night at $4^{\circ} \mathrm{C}$, then contents were decanted, plates were washed and dried as before.

To the coated plates, a final dilution of $1 / 10$ and $1 / 1$ of the tested serum and skim milk samples in (PBS $+1 \%$ bovine albumin) were added to every well in duplicates, including the control positive and negative sera as well as, the blank control, then covered and incubated at $37^{\circ} \mathrm{C}$ for 1 hour. Plates were decanted, washed three times using washing buffer, and then $100 \mu$ l of diluted conjugate (Rabbit-anti-bovine IgG, horse radish peroxidase labeled "Sigma chemical") 1/20000 was added to each well. Plates then covered and incubated at $37^{\circ} \mathrm{C}$ for 1 hour.

Plates were decanted, and washed 3 times with washing buffer solution, $100 \mu$ l of the substrate Orthophenyl-diamine (OPD) "Sigma chemical" was added to each well, then covered and incubated for 15 minutes at $37^{\circ} \mathrm{C}$. A brownish coloration indicating positive reaction was developed. The reaction was then stopped by adding $25 \mu \mathrm{l}$ per well of $1.25 \mathrm{Mol}$ of Sulphuric acid "Adwic", plates were read using ELISA reader "Dynatech"at $492 \mathrm{~nm}$.

\section{Serum Neutralization Test:}

The antibody titer against FMD using SNT and staining of tissue culture plates was determined according to the method described by Golding et al., (1976); Titers are expressed as the final dilution of serum 
present in the serum/virus mixture where $50 \%$ of wells are protected Karber (1931).

Interpretation of tests can vary between laboratories in regard to the negative/positive cut-off threshold. Laboratories should establish their own criteria by reference to standard reagents that can be obtained from the OIE Reference Laboratory at Pirbright OIE (2009). FMD vaccine is considered potent if it induced not less than $75 \%$ protection and S.N.T $1.5 \log _{10}$ Saad and Deghaidy, (2012). According to "FMD department, Veterinary Serum and Vaccine Research Institute-Agriculture research center, Cairo, Egypt" $1.2-1.5$ is considered to be doubtful titer.

\section{Statistical Analysis}

Data were analyzed using a computer statistical package (SPSS for windows,
Guide for personal computers, Release 6.1.3, Microsoft company, USA, 1993); data were presented as mean, standard error, $\mathrm{F}$ significance and correlation coefficient.

\section{Results}

All milk, BTM and serum samples collected from the three herds all over the year were subjected to indirect ELISA test and serum samples were subjected to SNT for the detection of specific antibodies against FMD Virus (01/93/ Aga strain). FMD antibody response in serum samples resulting from systemic vaccination with FMD vaccine using indirect ELISA and SNT is illustrated in figures (1), (3) and (5) and antibody response in individual and BTM samples using indirect ELISA is illustrated in figures (2), (4) and (6) (expressed in $\log 10)$. The 0 day is the day of starting collection of samples from the three herds, and arrows indicate date of vaccination.

\section{$\underline{\text { Farm A }}$}

A-S-FMD

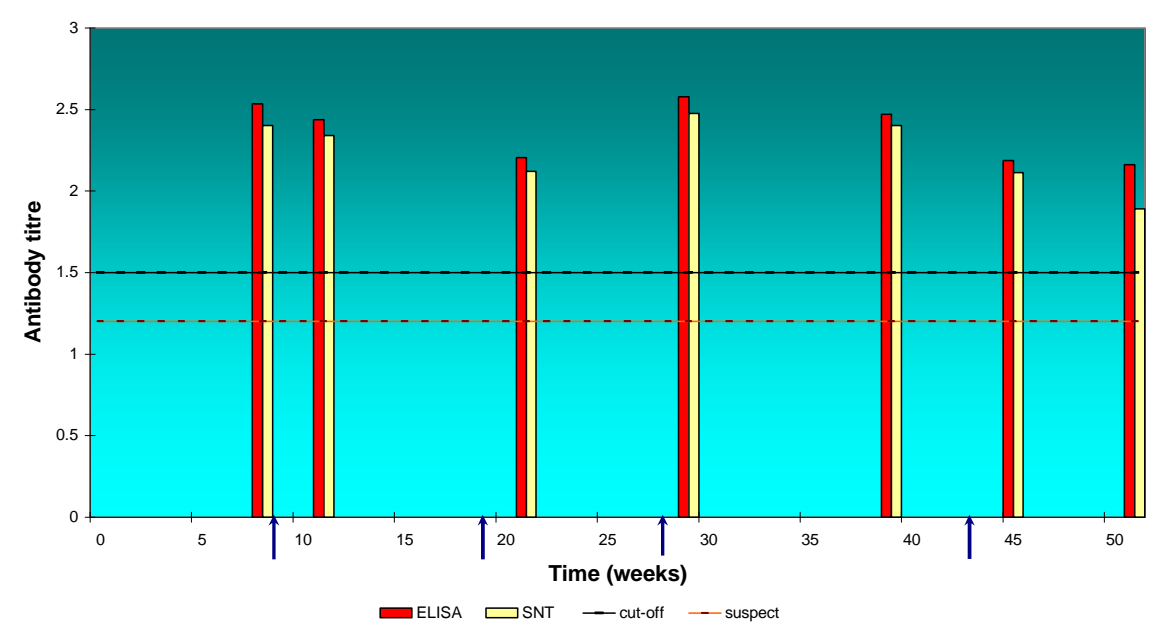

Fig. 1: Antibody Response (Expressed in $\log _{10}$ ) in Individual Serum Samples Result from Systemic Vaccination with FMD Vaccine at Farm "A", as Assessed by ELISA and SNT

The lesser extent of mean serum antibody titer is $2.16 \pm 0.12$ and the greatest value is $2.58 \pm 0.08$, and from $1.89 \pm 0.2$ to $2.48 \pm 0.08$ according to indirect ELISA and SNT respectively, a high protection level is obvious all year round. 


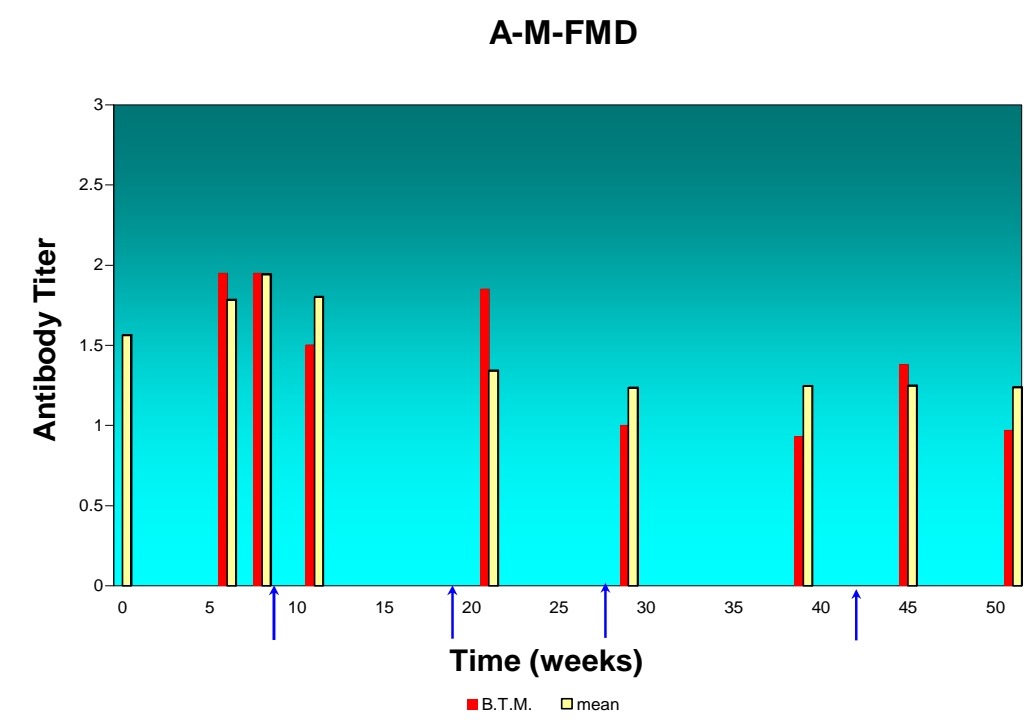

Fig. 2: Antibody Response (Expressed in $\log _{10}$ ) in Individual and BTM Samples Result from Systemic Vaccination with FMD Vaccine at Farm "A", as Assessed by ELISA

The lesser extent of mean milk antibody titers measured from samples of herd "A" was $1.24 \pm 0.03$ while the greatest value was
$1.94 \pm 0.01$; BTM antibody titer measured in the same occasion was 0.93 and 1.95 respectively.

\section{$\underline{\text { Farm B }}$}

B-S-FMD

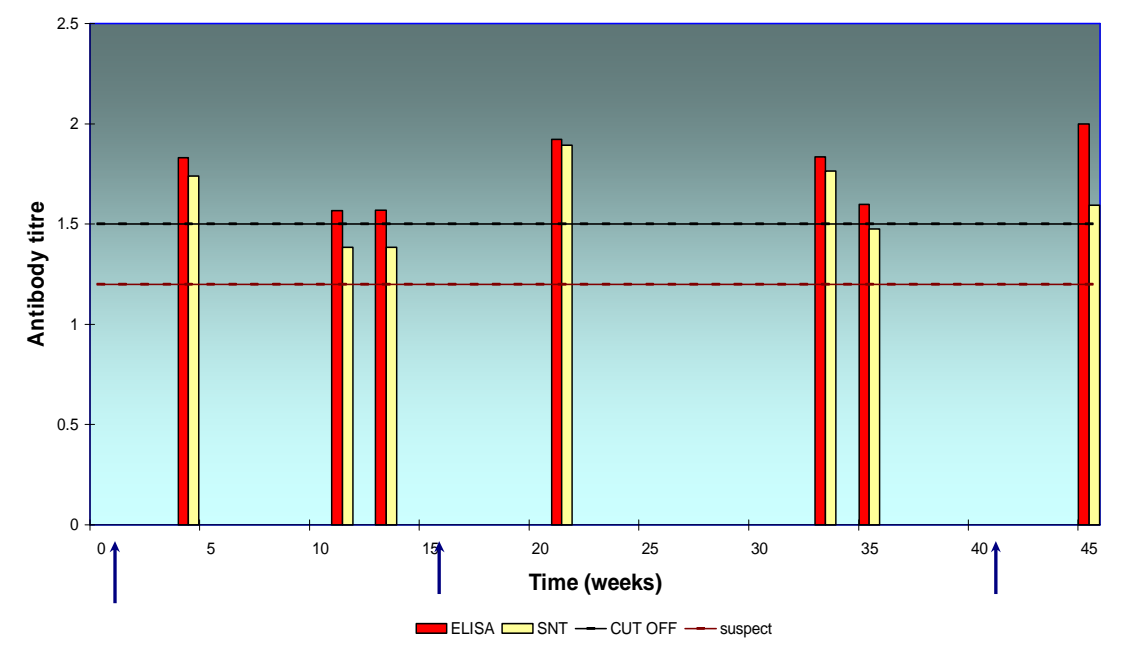

Fig. 3: Antibody Response (Expressed in $\log _{10}$ ) in Serum Samples Result from Systemic Vaccination with FMD Vaccine at Farm "B", as Assessed by ELISA and SNT

The lesser extent of mean serum antibody titer was $1.57 \pm 0.11$ and the greatest value was $2.00 \pm 0.18$, and from $1.38 \pm 0.15$ to
$1.59 \pm 0.2$ according to indirect ELISA test and SNT respectively, satisfied protection level is recorded. 


\section{B-M-FMD}

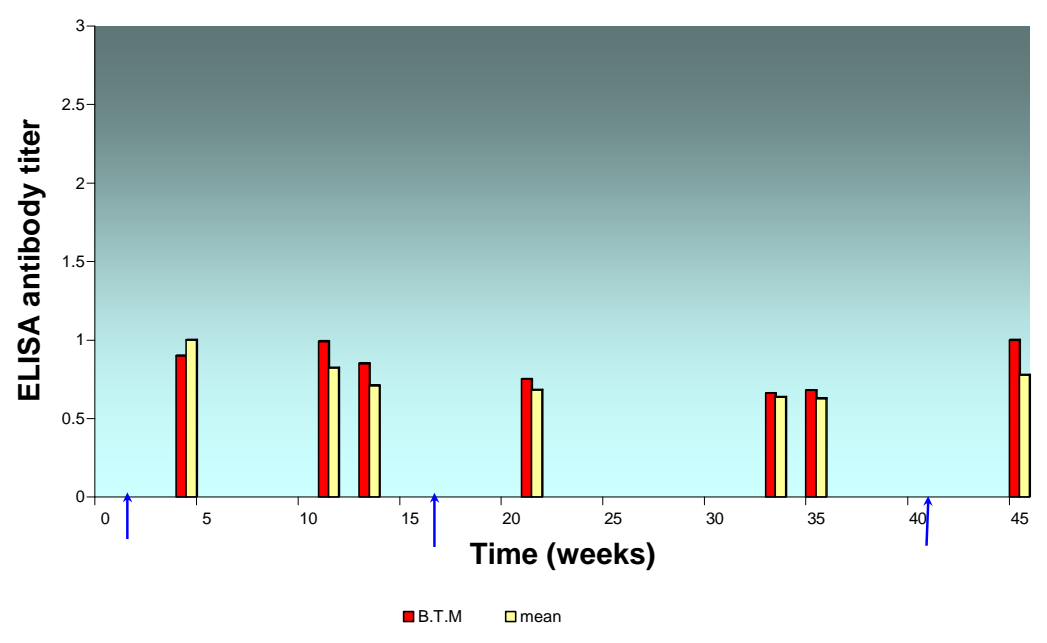

Fig. 4: Antibody Response (Expressed in $\log _{10}$ ) in Individual and BTM Samples Result from Systemic Vaccination with FMD Vaccine at Farm "B", as Assessed by ELISA

The lesser extent of mean milk antibody titers measured from samples of herd "B" was $0.63 \pm 0.02$ while the greatest value was $1.00 \pm 0.05$; BTM antibody titer measured in the same occasion was 0.68 and 0.9 respectively. The mean antibody titer in milk and BTM is less than herd "A".

\section{Farm C}

C-S-FMD

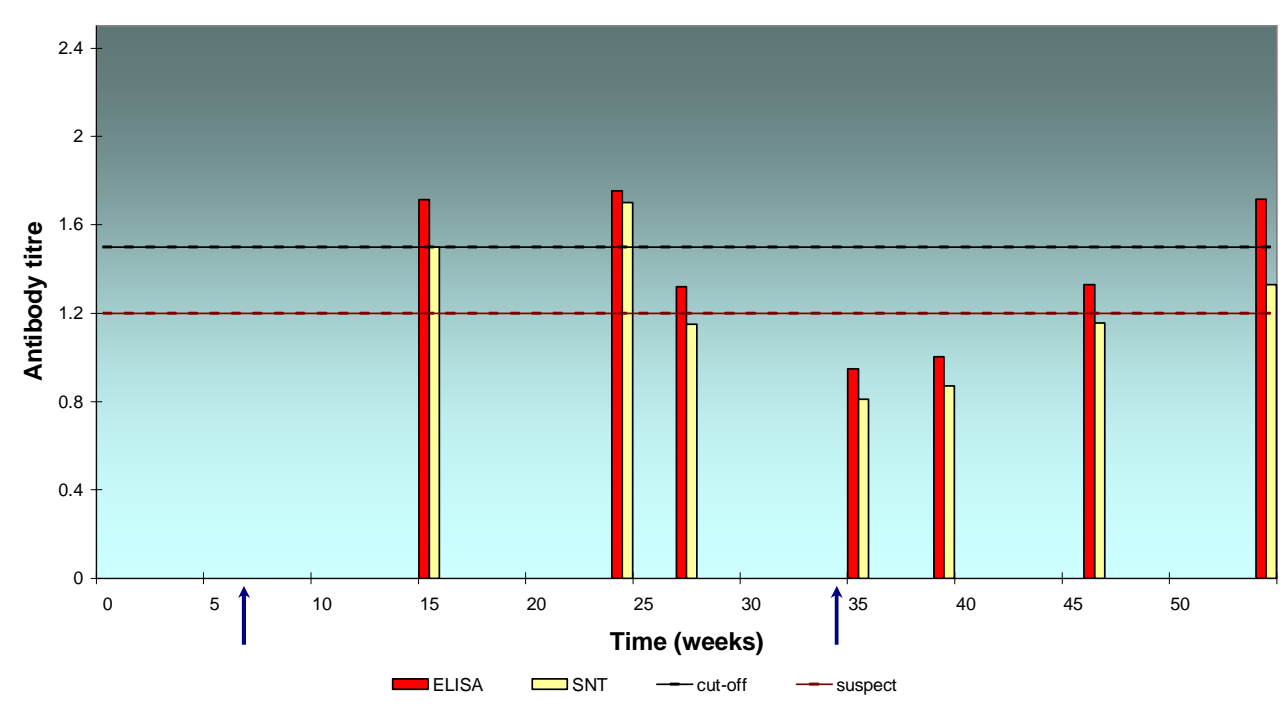

Fig. 5: Antibody Response (Expressed in $\log _{10}$ ) in Serum Samples Result from Systemic Vaccination with FMD Vaccine at Farm "C", as Assessed by ELISA

The lesser extent of mean serum antibody titer was $0.95 \pm 0.13$ and the greatest value was $1.75 \pm 0.15$, and from $0.81 \pm 0.13$ to
$1.7 \pm 0.15$ according to indirect ELISA test and SNT respectively, low protection level is recorded most of the year. 
C-M-FMD

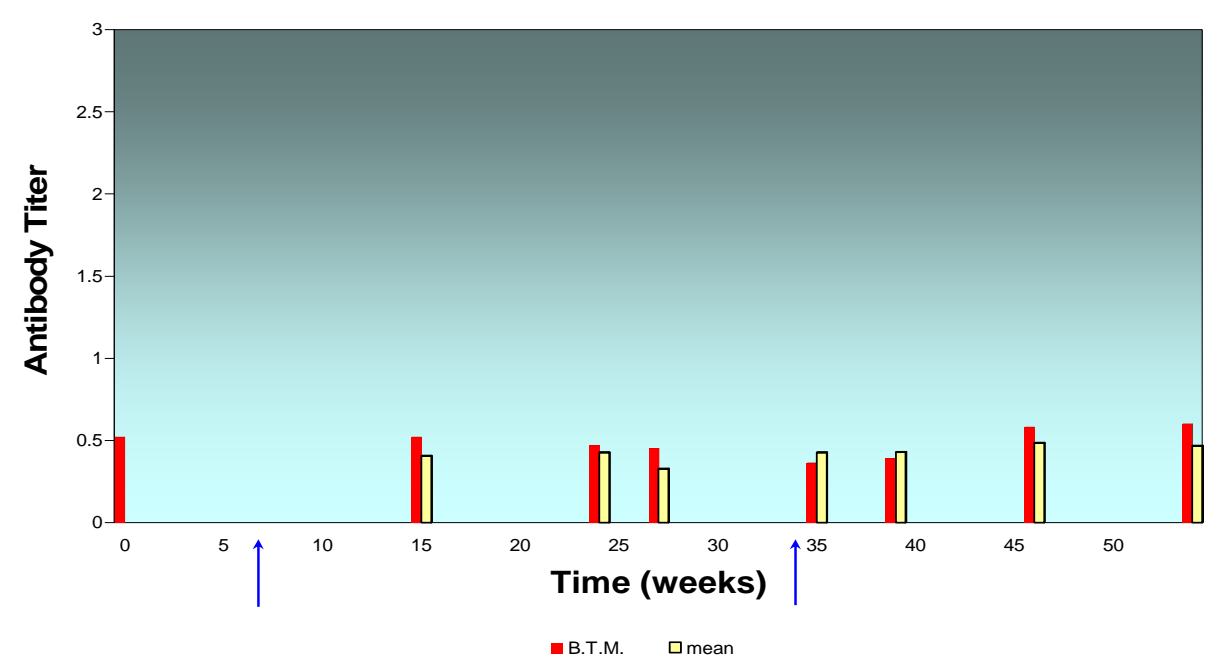

Fig. 6: Antibody Response (Expressed in $\log _{10}$ ) in Individual and BTM Samples Result from Systemic Vaccination with FMD Vaccine at Farm "C", as Assessed by ELISA

The lesser extent of mean milk antibody titers measured from samples of herd " $\mathrm{C}$ " was $0.33 \pm 0.08$ while the greatest value was $0.48 \pm 0.02$; BTM antibody titer measured in the same occasion was 0.45 and 0.58 respectively. The mean antibody titer in milk and BTM is less than other herds.

\section{Comparative Study of Total Population:}

According to the type of samples, FMD antibody response (serum (S), milk
(M) and BTM samples) resulting from systemic vaccination in the three herds using indirect ELISA is illustrated in figure (7), and different herds were compared in figure (8). Correlation coefficient and $\mathrm{F}$ test significance between FMD antibody titer in individual serum and corresponding milk samples at the three herds are presented in Figure (9).

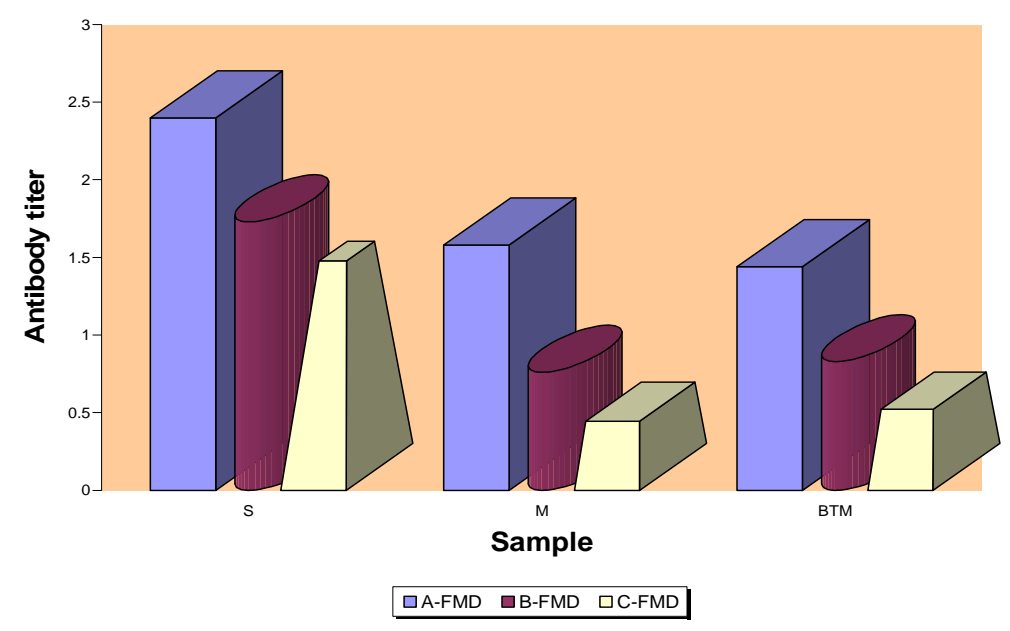

Fig. 7: Mean Antibody Response (Expressed in $\log _{10}$ ) in Different Samples Collected from the Three Herds, as Assessed by Indirect ELISA 


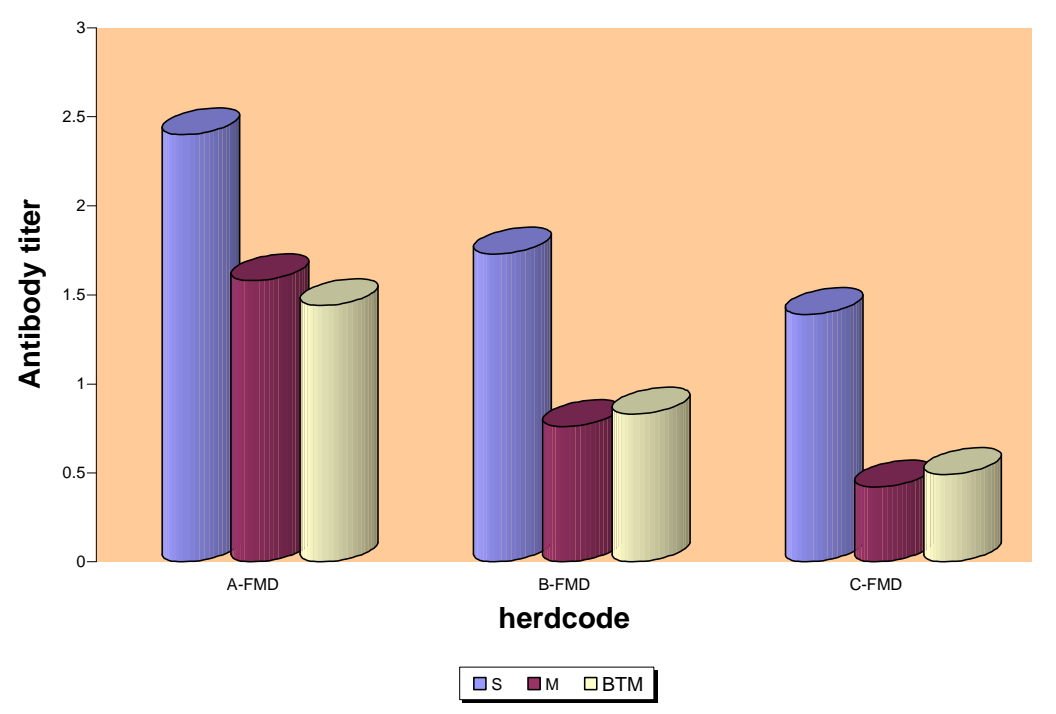

Fig. 8: Mean FMD Antibody Response in the Three Herds, as Assessed by Indirect ELISA

Comparing of antibody titers against FMD in the three herds showed that, the greatest value of FMD serum antibody titer is recorded at farm " $\mathrm{A}$ ", then farm "B" and the lesser extent was in farm "C". The same result was obtained in comparing of antibody titers in milk samples at herds "A", "B" and "C" respectively. These
Measuring FMD antibody titer in BTM samples which had been collected at the same time of individual serum and milk samples showed an antibody titer higher than or close to those measured in individual milk samples.

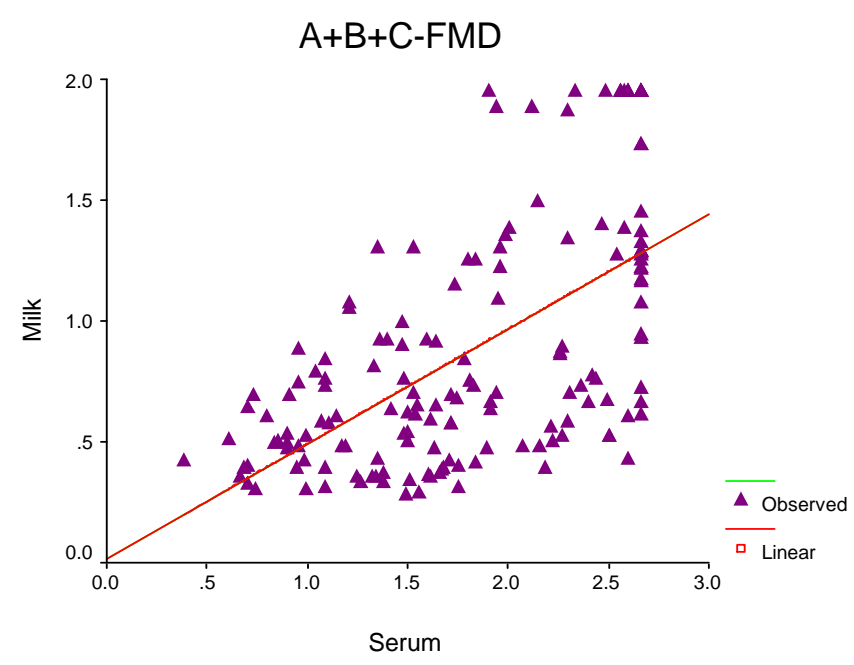

Fig. 9: Correlation between FMD Antibody Titer in Individual Serum and Milk Samples at the Three Herds

$\mathbf{r}=0.608$ (Pearson correlation is significant at the 0.01 level)

F significance $=0.000$

$\mathbf{Y}=0.4752 \mathrm{X}+0.0165$ 


\section{Discussion}

The present study was designed to evaluate FMD vaccination programs in three different commercial dairy herds, located at three different provinces (AL-fayoom (A), AL-Ismailia (B) and AL-Beheira (C)) using serum and milk samples, all animals were vaccinated with FMD "01/93/Aga" vaccine (Veterinary Serum and Vaccine Research-Cairo-Egypt). Vaccination of cattle twice annually is the government strategy for control of FMD virus in Egypt, but vaccination 3 or 4 times annually is the policy of some dairy farms to reach satisfied herd immunity all round the year.

The three herds were vaccinated four, three times and twice annually in herd A, B and $C$ respectively, herds management is considered good, milking machines were functioning adequately, and washing of udder and milker's hands was applied, post-dipping teat disinfection and clean muddy yards were present, Stainless-steel with a mixer and cooling system $\left(4^{\circ} \mathrm{C}\right)$ tanks for collection of milk were supplied.

Neutralizing antibodies could be detected all year round in milk from cows vaccinated annually against FMD virus Dhenninm et al., (1979), Serum antibody titer against FMD virus was measured in all farms using indirect ELISA and SNT revealed an antibody titer in ELISA results with an average of $(2.4 \pm 0.05),(1.7 \pm 0.07)$ and $(1.4 \pm 0.07)$ at herd "A", "B" and "C" respectively, while SNT results were in average of $(2.3 \pm 0.08),(1.6 \pm 0.08)$ and $(1.2 \pm 0.12)$ at herd "A", "B" and "C" respectively, ELISA titers were more closely related to protection than SNT titers as recorded by Hamblin et al., (1987). Coincidently mean titers in corresponding individual milk samples was $(1.58 \pm 0.04)$, $(0.8 \pm 0.02)$ and $(0.4 \pm 0.01)$ at herd "A", "B" and " $\mathrm{C}$ " respectively. These results indicate that all sampled animals responded to vaccination properly with high individual protection level in both farms "A" and "B" but not in farm "C", so FMD vaccine is found to be effective in producing immunization when used three times annually at herd "B" and higher satisfied protective level was recognized when vaccination applied four times annually at herd "A" but vaccination for twice annually was less than critical level (1.2-1.5) most of the year at herd "C". Although a high antibody titer was obtained when vaccination repeated for four times/year, the disadvantages of repeat vaccination is the stress effect which may leads to decrease production and immunosuppresion, local reaction, anaphylaxis, presence of inapparent infection Radostits et al., (1994) and the economical cost couldn't be ignored.

when data of total population of the three herds was tested a high moderate significant positive linear relationship $(r>6)$ is indicated using pearson correlation coefficient and $\mathrm{F}$ test significance between antibody titer in serum and corresponding milk samples. Similar results were obtained in previous work on different viruses (Bovine Herpes Virus-1 and Bovine Viral Diarrhea) vaccination but with different cut-off values Fayed et al., (2013), the effectiveness of vaccination and immunoglobulin concentration in milk may be influenced by several factors during lactation, the level of antibodies in milk showed an inverse relationship to the amount of milk produced Niskanen et al., (1989), acute inflammation and infection status of the mammary gland and some physiological factors such as the number and stage of lactation Caffin et al., (1983), stressful conditions and corticosteroid treatment Pastoret et al., (1982) and selective transport of immunoglobulins to the mammary glands, particularly during the early stage of lactation, is unique to ruminants Butler (1983). Although antibody concentrations are generally lower in milk than sera, equivalent test sensitivity can be achieved by using different cut-off values or different test dilutions Pritchard et al., (2002), milk is collected routinely on a daily basis and may represent a convenient method of measuring immunity at minimal cost, milk antibody levels can be a promising tool for FMD vaccine evaluation in situation where vaccination strategy applied, as recorded by Armstrong (1997) and Armstrong et al., (2000). 
Measuring FMD antibody titer in BTM samples which had been collected at the same time of individual serum and milk samples showed an antibody titer close to those measured in individual milk samples, so antibody titer in BTM may permit an adequate determination of immune status of herds.

Indirect ELISA test has many advantages over the SNT as it is independent of cell cultures and challenge viruses (milk samples couldn't be used in SNT), gives a test result within a few hours, is relatively inexpensive both to establish and run and are suitable for automation, this result support what was previously reported by Sandvik (2005).

In conclusion, protective antibody titer obtained from animals vaccinated three times/year with FMD vaccine is satisfied. Screening of antibody titer all round the year will help in the decision when reimmunization is needed once the percentage of animals having titers below the threshold considered protective reached a specific level, the use of milk rather than blood to monitor post-vaccinal immunity would represent a considerable saving in resources, and antibody titer in BTM permit an adequate determination of immune status but with different cut-off values in each herd according to different conditions of management and conditions.

\section{References}

Armstrong, R. M. (1997). "Development of Tests for Antibodies against Foot-andMouth Disease Virus in Cattle Milk," Journal of Virological Methods. Jan; 63 (1-2):17580 .

Armstrong, R. M. II (1997). "The Detection of Antibodies against Foot-and-Mouth Disease Virus in Sheep Milk" Journal of Virological Methods.69: 45-51.

Armstrong, R. M., Mathew, E. S. \& Mackay, D. K. (2000). "Validation of the Specific Isotype Assay to Detect Antibodies against Foot-and-Mouth Disease Virus in Bovine Milk," Journal of Virological Methods. Mar; 85(1-2):193-201.
Bradford, M. M. (1976). "A Rapid and Sensitive Method for the Quantitation of Microgram Quantities of Protein Utilizing the Principle of Protein-Dye Binding," Analytical Biochemistry, 72: 248-254.

Butler, J. E. (1983). "Bovine Immunoglobulins: An Augmented Review," Veterinary Immunology and Immunopathology. 4,433-152.

Caffin, J. P., Poutrel, B. \& Rainard P. (1983). "Physiological and Pathological Factors Influencing Bovine Immunoglobulin G1 Concentration in Milk," Journal of Dairy Science, 66:2161-2166.

Depa, P. M., Dimri, U., Sharma, M. C. \& Tiwari, R. (2012). "Update on Epidemiology and Control of Foot and Mouth Disease - A Menace to International Trade and Global Animal Enterprise," Veterinary World, 5(11), 694-704.

Dhenninm L., Labie, J. \& Gicquel, B. (1979). 'Recherche Sur Les Anticorps Anti O Aphteux Contecus Dams le Lait de Vachs Vaccines,' Bull. Acad.Vet. France 52, 513521.

Edwards, S., Woods, S. B., Westcott, D. G., Emmerson, M., Jones, P. C. \& Phillips, A. J. (1986). "An Evaluation of Five Serological Tests for the Detection of Antibody to Bovine Herpesvirus 1 in Vaccinated and Experimentally Infected Cattle," Research in Veterinary Science. Nov; 41(3):378-82.

Fayed, A. A. A., Abdel-Halim, M. M., Nabila S. Degheidy, Elbayoumy, M. K. \& Ghazy, A. A.M. (2013). "Detection of Bovine Herpesvirus 1 and Bovine Viral Diarrhea Virus Specific Antibodies in Individual, Bulk Tank Milk and Serum Samples of Vaccinated Cattle in Different Provinces of Egypt," International Journal of Veterinary Medicine: Research \& Reports. Vol. 2013, Article ID 516614, 17 Pages.

Golding, S. M., Hedger, R. S. \& Talbot, P. (1976). "Radial Immuno-Diffusion and Serum-Neutralization Techniques for the Assay of Antibodies to Swine Vesicular Disease," Research in Veterinary Science, 20, 142-147. 
Hamblin, C., Kitching, R. P., Donaldson, A. I., Crowther, J. R. \& Barnett, I. T. R. (1987). "Enzyme-Linked Immunosorbent Assay (ELISA) for the Detection of Antibodies against Foot-and-Mouth Disease Virus: III.Evaluation of Antibodies after Infection or Vaccination," Epidemiology and Infection. 99, 733-744.

Karber, G. (1931). 'Beitrage Zur Kille Kiven Behand-Lung Pharmakologis ReihenverSuche Naunyn Schiede Berg,' NaunynSchmiedeberg's Archives of Pharmacology; 126: $280-283$.

Niskanen, R., Alenius, S., Larsson, B. \& Jacobsson, S. O. (1991). "Determination of Level of Antibodies to Bovine Viral Diarrhea Virus (BVDV) in Bulk Tank Milk as a Tool in the Diagnosis and Prophylaxis of BVDV Infections on Dairy Herds," Archives of Virology. (Supp3) 245-251.

Niskanen, R., Alenius, S., Larsson, B. \& Juntti, N. (1989). "Evaluation of an EnzymeLinked Immunosorbent Assay for Detection of Antibodies to Bovine Virus Diarrhoea Virus in Milk," Zentralbl. Veterinarmed. B. 36(2) 113-118.

Nylin, B., Stroger, U. \& Ronsholt, L. (2000). "A Retrospective Evaluation of a Bovine Herpesvirus-1 (BHV-1) Antibody ELISA on Bulk-Tank Milk Samples for Classification of the BHV-1 Status of Danish Dairy Herds," Preventive Veterinary Medicine, (47) 91105.

OIE Terrestrial Manual (2009). Chapter 2.1.5. - Foot and Mouth Disease.

Pastoret, P. P., Thiry, E., Brochier, B. \& Derboven G. (1982). "Bovid Herpesvirus 1 Infection of Cattle: Pathogenesis, Latency, Consequences of Latency," Annales de Recherches Veterinaires, 13, 221-235.

Pritchard, G. C., Kirkwood, G. M. \& Sayers, A. R. (2002). "Detecting Antibodies to Infectious Bovine Rhinotracheitis and BVD Virus Infectious Using Milk Samples from Individual Cows" Veterinary Record, February 9.

Radostits, O. M., Blood, D. C. \& Gay, C. C. (1994). 'Veterinary Medicine,' Bailliere
Tindall, 24-28 Oval Road, London NW1 7DX.

Rodriguez, L. L. \& Grubman, M. J. (2009). "Foot and Mouth Disease Virus Vaccines," Vaccine 27(Suppl 4):D90-D94.

Saad, M. A. \& Deghaidy, W. (2012). "Comparative Evaluation of Foot and Mouth Disease Vaccines Used in Egypt," Nature and Science, 2012; 10(1).

Sandvik, T. (2005). "Selection and Use of Laboratory Diagnostic Assays in BVD Control Programs," Preventive Veterinary Medicine. Nov 15; 72(1-2):3-16; Discussion 215-9. Epub 2005 Sep 13.

Sumption, K., Rweyemamu, M. \& Wint, W. (2008). "Incidence and Distribution of Foot-and-Mouth Disease in Asia, Africa and South America; Combining Expert Opinion, Official Disease Information and Livestock Populations to Assist Risk Assessment," Transboundary and Emerging Diseases 55:5-13.

Van Maanen, C. (1990). "A ComplexTrapping-Blocking (CTB) ELISA, Using Monoclonal Antibodies and Detecting Specifically Antibodies Directed Against Foot-and-Mouth Disease Type A, 0 and C $\Pi$ Application," Veterinary Microbiology, 24 (1990) 179-191.

Voller, A., Bidwell, D. E. \& Ann Bartlett (1976). "Enzyme Immuno Assay in Diagnostic Medicine, Theory and Practice," Bulletin of the World Health Organisation, 53: $55-65$

Wagner, G. G, Card, J. L. \& Cowan, K. M. (1969). 'Immunochemical Studies of Footand-Mouth Disease,' Plum Island Animal Disease Laboratory, Animal Disease and Parasite Research Division Agriculture Research Service, V.S. Department of Agricultural, Greenport New York, USA.

Zadnik, T., Klinkon, M., Nemec, M. \& Mesaric, M. (2001). 'The Analysis of Weekly Milk Bulk Tank Components as a Routine Indicator of Herd Health Status,' Israel Journal of Veterinary Medicine, Vol.56 (2) 2001. 